\title{
The inventions in nanotechnologies as practical solutions. Part IV
}

\author{
Authors: \\ Leonid A. Ivanov, \\ Vice President, the International Academy of Engineering, Moscow, Russian Federation, \\ L.a.ivanov@mail.ru;
}

\section{Petr S. Prokopiev,}

Student, Financial University Under the Government of the Russian Federation, International Economic Relations Faculty, e-mail: prokopiev2012@gmail.com

\begin{abstract}
A brief review of patents is given. The research performed by scientists, engineers and specialists in the area of nanotechnologies and nanomaterials resulted in increased efficiency of construction, housing sector and adjacent fields of economy. For example, the invention «Carbon ceramic fiber-reinforced composite material and method for its production» refers to a class of carbon-based composite materials of heat-shielding, structural, chemical-resistant purposes, can be used under static and dynamic loads when heated to $2000^{\circ} \mathrm{C}$ in an oxidizing environment (aerospace engineering, construction facilities for special purposes, high-temperature electrothermal equipment, equipment for nuclear reactors, etc.). The technical result of the invention is the strength of the composite increased up to $40 \%$ in terms of flexural strength and twice in terms of compressive strength.

The specialists can also be interested in the following inventions in the area of nanotechnologies: building construction elements; a method for synthesizing a composite carbon material with metal nanoparticles with transferring a part of their electron density to a carbon matrix; a method of manufacturing marker of fuel and lubricants; wastewater treatment system with nano-modified natural sorbents; nanocrystal, hydrosol of nanocrystalline cellulose and method for producing it; a method for producing membranes for ultrafiltration of aqueous media; a method of obtaining transparent ceramics of yttrium-aluminum garnet; method and device for atomic emission spectral analysis of nanoobjects, etc.
\end{abstract}

Keywords: nanotechnologies in construction, nanoparticles, nanomodified sorbents, nanocrystal, nanoobjects, carbon nanotubes, nanostructures.

For citation: Ivanov LA., Prokopiev P.S. The inventions in nanotechnologies as practical solutions. Part IV. Nanotehnologii v stroitel'stve $=$ Nanotechnologies in Construction. 2019, Vol. 11, no. 4, pp. 447-457. DOI: 10.15828/2075-8545-2019-11-4-447-457.

Machine-readable information on CC-licenses (HTML-code) in metadata of the paper

$<$ rel="license" href="http://creativecommons.org/licenses/by/4.0/" ><img alt="Creative Commons License" style="border-width:0" src="https://i.creativecommons.org/l/by/4.0/88x31.png" / ></a $><$ br $/><$ span xmlns:dct="http://purl.org/dc/terms/" href="http://purl.org/dc/dcmitype/Text" property="dct:title" rel="dct:type" $>$ The inventions in nanotechnologies as practical solutions. Part IV $</$ span $>$ by $<$ a xmlns:cc="http://creativecommons.org/ns\#" href="Nanotehnologii v stroitel'stve $=$ Nanotechnologies in Construction. 2019, Vol. 11, no. 4, pp. 447-457. DOI: 10.15828/2075-8545-2019-11-4-447-457" property="cc:attributionName" rel="cc:attributionURL">Ivanov LA., Prokopiev P.S. $<$ /a $>$ is licensed under a $<$ a rel="license" href="http://creativecommons.org/licenses/by/4.0/" $>$ Creative Commons Attribution 4.0 International License $</ \mathrm{a}>$. $<$ br / >Based on a work at $<$ a xmlns:dct="http://purl.org/dc/terms/" href="http://nanobuild.ru/en_EN/nanobuild-4-2019/" rel="dct:source" $>$ http://nanobuild.ru/en_EN/nanobuild-4-2019/</a $>.<\mathrm{br} />$ Permissions beyond the scope of this license may be available at $<$ a xmlns:cc="http://creativecommons.org/ns\#" href="L.a.ivanov@mail.ru"rel="cc:morePermissions">L.a.ivanov@mail.ru</a> .

The paper has been received by editors: 28.06.2019.

The paper has been received by editors after peer-review: 19.07.2019.

The paper has been accepted for publication: 02.08.2019. 


\title{
Изобретения в области нанотехнологий, направленные на решение практических задач. Часть IV
}

\author{
Авторы: \\ Иванов Леонид Алексеевич, \\ вице-президент, Международная инженерная академия, \\ г. Москва, Россия, L.a.ivanov@mail.ru \\ Прокопьев Пётр Сергеевич, \\ студент факультета международных экономических отношений Финансового университета \\ при Правительстве Российской Федерации, prokopiev2012@gmail.com
}

Резюме: В реферативной форме проводится обзор изобретений, результаты творческой деятельности ученых, инженеров и специалистов, в т.Ч. и изобретения, которые в области нанотехнологий и наноматериалов позволяют в строительстве, жилищно-коммунальном хозяйстве, смежных отраслях экономики добиться значительного эффекта. Например, изобретение «Углеродкерамический волокнисто-армированный композиционный материал и способ его получения» относится к классу композиционных материалов на основе углерода теплозащитного, конструкционного, химостойкого и назначений, подлежащих эксплуатации в условиях статических и динамических нагрузок при нагреве до $2000^{\circ} \mathrm{C}$ в окислительной среде (авиакосмическая техника, строительство объектов специального назначения, высокотемпературное электротермическое оборудование, комплектация атомных реакторов и т.п.). Технический результат изобретения - увеличение прочности композита до 40\% по показателю прочности при изгибе и в два раза по показателю прочности при сжатии.

Также представляют интерес для специалистов следующие изобретения в области нанотехнологий: строительный конструкционный элемент; способ синтеза композитного углеродного материала с наночастицами металла с переносом части их электронной плотности в углеродную матрицу; способ изготовления маркёра горючесмазочных материалов; система очистки сточных вод с использованием наномодифицированных природных сорбентов; нанокристалл, гидрозоль нанокристаллической целлюлозы и способ его получения; способ получения мембран для ультрафильтрации водных сред; способ получения прозрачной керамики иттрий-алюминиевого граната; способ и устройство атомно-эмиссионного спектрального анализа нанообъектов и др.

Ключевые слова: нанотехнологии в строительстве, наночастицы, наномодифицированные сорбенты, нанокристалл, нанообъекты, углеродные нанотрубки, наноструктуры.

Для цитирования: Иванов Л.А., Прокопьев П.С. Изобретения в области нанотехнологий, направленные на решение практических задач. Часть IV // Нанотехнологии в строительстве. - 2019. - Том 11, № 4. - C. 447-457. - DOI: 10.15828/20758545-2019-11-4-447-457.

Машиночитаемая информация о CC-лицензиях (HTML-код) в метаданных статьи

$<$ a rel="license" href="http://creativecommons.org/licenses/by/4.0/" ><img alt="Creative Commons License" style="border-width:0" src="https://i.creativecommons.org///by/4.0/88x31.png"/></a $><$ br / ><span xmlns:dct="http://purl.org/dc/terms/" href="http://purl.org/dc/dcmitype/Text" property="dct:title" rel="dct:type" $>$ The inventions in nanotechnologies as practical solutions. Part IV $</$ span $>$ by $<$ a xmlns:cc="http://creativecommons.org/ns\#" href="Nanotehnologii v stroitel'stve = Nanotechnologies in Construction. 2019, Vol. 11, no. 4, pp. 447-457. DOI: 10.15828/2075-8545-2019-11-4-447-457" property="cc:attributionName" rel="cc:attributionURL">Ivanov LA., Prokopiev P.S. $</$ a $>$ is licensed under a $<$ a rel="license" href="http://creativecommons.org/licenses/by/4.0/" $>$ Creative Commons Attribution 4.0 International License $</ a>$. $<$ br / $>$ Based on a work at $<$ a xmlns:dct="http://purl.org/dc/terms/" href="http://nanobuild.ru/en_EN/nanobuild-4-2019/" rel="dct:source" $>$ http://nanobuild.ru/en_EN/nanobuild-4-2019/</a $>$. $<$ br $/>$ Permissions beyond the scope of this license may be available at $<$ a xmlns:cc="http://creativecommons.org/ns\#" href="L.a.ivanov@mail.ru" rel="cc:morePermissions" $>$ L.a.ivanov@mail.ru</a $>$.

Статья поступила в редакцию: 28.06.2019.

Статья поступила в редакцию после рецензирования: 19.07.2019.

Статья принята к публикации: 02.08.2019. 


\section{INTRODUCTION}

$\mathrm{T}$ he practical application of the results achieved by scientists, engineers and specialists can become efficient tool to increase number of import-substituting goods and to rise labor productivity. An invention is known to be a new, with distinctive characteristics technical solution with proved efficiency (new technologies, structures or new substances). The paper reviews the essence, technical result and practical value of some inventions concerning nanotechnologies.

\section{MAIN PART}

Carbon ceramic fiber-reinforced composite material and method for its production (RU $2684538 \mathrm{C1}$ )

The invention relates to a class of carbon-based composite materials for heat-shielding, structural, chemicalresistant purposes to be operated under static and dynamic loads when heated to $2000^{\circ} \mathrm{C}$ in an oxidizing environment (aerospace engineering, construction of special-purpose facilities, high-temperature electrothermal equipment, atomic reactor equipment and etc.), as well as to methods for their preparation [1]. The technical result of the invention is strength of the composite increased up to $40 \%$ in terms of flexural strength and twice in terms of compressive strength.

The carbon ceramic composite material includes a ceramic matrix reinforced with carbon fiber material. The matrix ceramic material is additionally reinforced with carbon nanotubes and additionally contains nanostructured carbide-silicon interphase at the interface between the nanostructured matrix and the reinforcing carbon-fiber filler in the following ratio of components, wt.\%: carbon nanotubes $0.3-1.0$, carbon fiber materials $15-25$, nanostructured carbide silicon interphase $2-4$, silicon carbide - the rest. The carbon fiber filler is impregnated with a mixture of non-coking and coking forming oligomeric resins, placed between the transport and separation polyethylene films and subjected to ionizing radiation, which is partially polymerized with noncoking resin. From the prepreg layers, a billet package of a bulk structure is formed, then molding, carbonization, impregnation with a solution of polycarbosilane in toluene, drying, thermal stabilization, ceramization, and siliconization are carried out. Before placing the impregnated carbon fiber filler onto the transport and separating polyethylene films, a layer of $(2-10) \%$ carbon nanotube suspension in a mixture of coke-forming oligomeric and non-coking resins is applied. When laying out a package of CFRP blanks, carbon nanotubes are poured into each of the prepreg layers through a removable perforated plate that is in direct close contact with the prepreg layer that is laid out, repeating its dimensions. After carbonization, the resulting carbon-carbon preform is additionally compacted by impregnation in $(2-10) \%$ suspension of carbon nanotubes in a solution of polycarbosilane in toluene.

\section{The method of obtaining thin diamond films (RU 2685665 C1)}

The invention can be used in various fields of industry and science to obtain thin-film reinforcement coatings and active layers of thin-film nanostructures [2]. A method is proposed for producing thin diamond films on a substrate by the method of vacuum laser impact on targets and carbon condensation on substrates, where pre-pressed detonation nanodiamond tablets and high-purity graphite tablets are used as targets, and laser irradiation is carried out in two stages: first, focusedbased laser radiation Yttrium aluminum garnet with a wavelength of $1064 \mathrm{~nm}$ in a series of 10-20 pulses with a pulse energy of 3.8-5.8 $\mathrm{J}$ disperses the target from detonation nanodiamond and form on the substrate nanodiamond nucleation centers; then the gaps between the nucleation centers are filled with carbon with predominantly sp 3 bonds condensed from the vapor-gaseous phase obtained by evaporating a target from high-purity graphite by exposure to defocused laser radiation of the same laser with a pulse energy intensity not lower than $1.6 \cdot 104 \mathrm{~W} / \mathrm{cm}^{2}$. In the course of carbon condensation on a substrate preliminarily populated with nucleation centers, mainly with dimensions of $5.73 \mathrm{~nm}$, they grow to particles of about $285.15 \mathrm{~nm}$. The combination of such particles forms a flat thin-film close-packed hexagonal structure, which is a polycrystalline aggregate of islands, which are crystallographically equally oriented relative to the film surface.

\section{Rotor vibration mixer (RU 2685674 C1)}

The invention relates to mixing devices for mixing highly dispersed substances and nano-substances and can be used in chemical, petrochemical, food, agricultural and other industries [3]. The rotor-vibration mixer includes a case, a mixing body and a vibrator, a case cover, a mixing body made in the form of a propeller mounted coaxially above the mixing body of an anchor form, the vibrator being made in the form of a rotary comb guide. The invention provides an increase in the efficiency of mixing highly dispersed and nano-substances, and consequently, an increase in the quality of the finished mixture due to the use of ultrasonic vibrations in the fluidized bed.

The method of synthesis of nanocomposites $\mathrm{Ag} / \mathrm{C}$ (RU 2686223 C1)

The invention relates to the field of chemistry and nanotechnology. The method of synthesis of $\mathrm{Ag} / \mathrm{C}$ 
nanocomposites includes the preparation of combined solution of polyacrylonitrile (PAN) and silver nitrate in dimethylformamide (DMF), holding all the components to complete dissolution, removing dimethylformamide by evaporation and heating the resulting solid residue [4]. Preparation of combined solution of polyacrylonitrile and $\mathrm{AgNO}_{3}$ in dimethylformamide is carried out at a temperature of $30-70^{\circ} \mathrm{C}$ in the following ratio of components: polyacrylonitrile $4.7 \%$, dimethylformamide $93.8-94.6 \%$, $\mathrm{AgNO}_{3} 0.7-1.5 \%$. Evaporation of dimethylformamide is carried out at $60-80^{\circ} \mathrm{C}$. A gradual infrared heating of the obtained solid residue is carried out at a pressure of $10-2-10-3 \mathrm{~mm} \mathrm{Hg}$. First, preheating is carried out for $5-15$ minutes at $80-200^{\circ} \mathrm{C}$ with a heating rate of no more than $50^{\circ} \mathrm{C} / \mathrm{min}$. The final heating is carried out for $5-15$ minutes at $80-700^{\circ} \mathrm{C}$ with a heating rate of not more than $50^{\circ} \mathrm{C} / \mathrm{min}$. The invention makes it possible to simplify the production of nanocomposites, including $\mathrm{Ag}$ silver nanoparticles with a size of $19-28 \mathrm{~nm}$ in a carbon matrix, without the use of additional external reducing agents.

\section{C1)}

\section{Cutting tool with wear-resistant coating (RU 2685820}

The invention relates to metal-cutting tools, in particular to cutting plates and cutters used for processing products from difficult-to-process materials, including titanium and its alloys [5]. A wear-resistant cutting tool comprising cutting edges formed at the intersection of the front and rear surfaces of a hard-alloy cutting base, in which the wear-resistant coating includes at least a structure formed of $\mathrm{TiB}_{2}$. The structure formed of $\mathrm{TiB}_{2}$ contains at least a sequentially deposited intermediate layer of $\mathrm{TiB}_{2}$ and a wear-resistant layer of $\mathrm{TiB}_{2}$. The intermediate layer has a columnar metallographic structure with preferential orientation 001 . The wear-resistant layer comprises at least a layer with an internal structure with textured nanocolumn grains with an orientation of 001 with amorphous p-phase within the boundaries of the said grains. The effect is increased durability of cutting tools with coating containing $\mathrm{TiB}_{2}$.

\section{A method of manufacturing products with antistatic properties (RU $2685120 \mathrm{C1}$ )}

The invention relates to the field of composite materials and represents a method of manufacturing a composite fiberglass sheet with antistatic properties and products obtained from it [6]. A method of manufacturing a composite fiberglass antistatic in terms of a sheet with a thickness of 0.5 to $10.0 \mathrm{~mm}$ for the manufacture of pressed products consists of the following stages: in the first stage polyester resin and powder additives with a nanocomponent, which makes the sheet to be antistatic, are mixed in a dissolver to form a paste, which is supplied to the containers, from where it is applied to the films moving under them in the second stage, and in the second stage chemical thickening of the polyester resin is applied by incorporating a viscosity increasing agent into paste for further pressing after $3-5$ days, and at the same time reinforcing fiberglass is fed to a cutting machine located above the paste surface applied to one of the films, reinforcing fiberglass is cut into segments of a specified length and randomly fed to the surface of the paste layer, from above roll the second layer of film with a paste and serves in the sealing system of the rollers, where the fiberglass is impregnated and air bubbles are removed, the result is a sheet that is wound on steel rollers on the rack. The resulting sheet is cut on the table, removing the edges depleted in fiberglass, while cuttings are put in the center of the sample in a pile, which is placed in the mold, then the product is form. The invention provides antistatic properties to the sheet and the finished product from it by all of its volume.

\section{A method of manufacturing a diamond tool with nano- modified cutting part (RU 2685917 C1)}

The invention relates to the manufacture of tools for cutting solid and highly solid materials and can be used for the manufacture of diamond cutting tools, in particular, the stone diamond cutting wheel with water and/or air cooling for cutting reinforced concrete, brick, porcelain stoneware, refractory materials of granite, marble and other minerals [7].

The technical result is a method of manufacturing a diamond tool with nanomodified cutting part. The method includes preparation of powder mixture based on diamond powder and ligament, introduction of plasticizer into the mixture, granulating, dosing, cold pressing of the cutting part of the tool, hot pressing, tumbling, connecting the cutting part to tool and diamond cutting.

Installation of plasma-chemical synthesis of nanosized powders and the cyclone used in it (RU $2686150 \mathrm{C1}$ )

The installation contains a reactor, the casing of which is located vertically and made with the possibility of heating, an electron accelerator with an electron energy of $300-1000 \mathrm{keV}$, a system for feeding the reagent into the reactor containing the supply tank, the dispenser, the buffer tank and the shut-off valve, a vacuum system, a device for separating solid and gaseous products of plasmachemical synthesis, made in the form of a screw cyclone with the possibility of heating its body, and a system for separating soluble gaseous products of plasma-chemical synthesis associated with by a certain cyclone through an electrostatic filter, while the reactor outlet and the screw cyclone inlet are separated by an automatic discharge valve [8]. 
The invention relates to equipment for the plasmachemical synthesis of ultrafine powders, inorganic compounds and compositions, in particular to the installation of the plasma-chemical synthesis of nanoscale powders and the screw cyclone used in it. The invention provides the possibility to obtain various types of products of nanosized powders and composite materials based on them with high chemical purity on the same equipment, as well as to reduce the time of technological transition from one process to another and an efficient economic effect.

The method of synthesis of metal nanoparticles by deposition on a porous carbon material (RU $2685564 \mathrm{C1}$ )

The invention relates to the production of metal nanoparticles. The method involves the evaporation of target from a metal by an electron beam in vacuum and the deposition of metal nanoparticles [9]. The evaporation of target from metal is conducted by an electron beam directed at the angle of 30-90 degrees to the target surface. The method provides spatial scanning of the electron beam in two coordinates on the target with frequencies within $5-200 \mathrm{~Hz}$ and amplitude $5 \mathrm{~mm}$ for $10-1000$ seconds and temporal modulation of the beam current with a frequency of $10-100 \mathrm{~Hz}$ with a duty cycle of $1-10$. The deposition of metal nanoparticles is carried out from a directional flow on a substrate covered with a porous carbon material with a thickness of $0.1-2 \mathrm{~mm}$, bulk density $0.04-0.06 \mathrm{~g} / \mathrm{cm}$ and set on a water-cooled copper screen. The result is reduced energy absorption in metal vapors, which increases spraying performance.

A method of manufacturing a gas sensor with a nanostructure with a superdeveloped surface and a gas sensor based on it (RU 2687869 C1)

A method of manufacturing a gas sensor with a nanostructure with a super-developed surface is based on forming a heterostructure of various materials in which a gas-sensitive layer is arranged. After that, it is fixed in the sensor case, and the contact pads are connected to the conclusions of the case using contact conductors, the gassensitive layer is formed in the form of a nanostructure with a super-developed surface by two-stage chemical synthesis. At the first stage, which forms a homogeneous thin film of zinc oxide, which is a germinal layer, and at the second stage, zinc oxide nanorods are formed, forming a superdeveloped surface [10].
The technical result is the possibility to increase sensitivity to the gas-reductors under the temperature close to the room one $\left(25-50^{\circ} \mathrm{C}\right)$.

These are inventions in nanotechnological area that can be interesting for specialists:

- Building construction element [11].

- The method of synthesis of a composite carbon material with metal nanoparticles with the transfer of a part of their electron density into a carbon matrix [12].

- A method of manufacturing a marker of fuel and lubricants [13].

- The system of wastewater treatment based on nanomodified natural sorbents [14].

- Nanocrystal, hydrosol of nanocrystalline cellulose and method for producing it [15].

- A method for producing membranes for ultrafiltration of aqueous media [16].

- Energy efficiency technologies [17].

- The method of obtaining transparent ceramics of yttrium-aluminum garnet [18].

- Global energy market development trends [19].

- Method and device for atomic emission spectral analysis of nanoobjects [20].

- The method of thermal cleaning of carbon nanotubes [21].

- The method of obtaining durable and conductive fibers by pulling films of carbon nanotubes [22].

\section{CONCLUSION}

It is known that it is precisely the popularization and introduction of inventions that is an important factor for the success of many successful companies. For example, General Electric, which entered world history as one of the most innovative companies of the 20th century, is a company that was originally listed in the Dow Jones index in 1896 and is still there. Therefore, we hope that the information published in this section will be in demand and useful for specialists. Confirmation that articles from the «Invention Review» column are particularly popular is information on the number of views of materials, for example, in the full-text database of open access scientific journals Open Academic Journals Index OAJI (USA), link - http://oaji.net/ journal-detail. html? number $=6931$. 


\section{ВВЕДЕНИЕ}

$\mathrm{B}$ современных условиях использование изобретений ученых, инженеров и специалистов может способствовать эффективному решению задач импортозамещения и повышения производительности труда. Как известно, изобретение - это новое, обладающее существенными отличиями решение технической задачи, обеспечивающее положительный эффект (новые технологии, конструкции, новые вещества). В статье рассмотрены сущность, технический результат, практическая значимость некоторых изобретений, относящихся к области нанотехнологий.

\section{ОСНОВНАЯ ЧАСТЬ}

Углеродкерамический волокнисто-армированный композиционный материал и способ его получения (RU 2684538 C1)

Изобретение относится к классу композиционных материалов на основе углерода теплозащитного, конструкционного, химостойкого и назначений, подлежащих эксплуатации в условиях статических и динамических нагрузок при нагреве до $2000^{\circ} \mathrm{C}$ в окислительной среде (авиакосмическая техника, строительство объектов специального назначения, высокотемпературное электротермическое оборудование, комплектация атомных реакторов и т.п.), а также к способам их получения [1]. Технический результат изобретения - увеличение прочности композита до $40 \%$ по показателю прочности при изгибе и в два раза по показателю прочности при сжатии.

Углеродкерамический композиционный материал включает керамическую матрицу, армированную углеродным волокнистым материалом. При этом матричный керамический материал дополнительно армирован углеродными нанотрубками и дополнительно содержит по границе раздела фаз наноструктурированной матрицы и армирующего углеволокнистого наполнителя наноструктурированную карбидкремниевую интерфазу при следующем соотношении компонентов, мас.\%: углеродные нанотрубки 0,3-1,0, углеродные волокнистые материалы 15-25, наноструктурированная карбидкремниевая интерфаза 2-4, карбид кремния остальное. Углеродный волокнистый наполнитель пропитывают смесью некоксующейся и коксообразующей олигомерных смол, помещают между транспортной и разделительной полиэтиленовыми пленками и подвергают ионизирующему облучению, которым частично полимеризуют некоксующуюся смолу. Из слоев препрега набирают пакет заготовки объемной структуры, проводят формование, кар- бонизацию, пропитку раствором поликарбосилана в толуоле, сушку, термостабилизацию, керамизацию и силицирование. Перед помещением пропитанного углеродного волокнистого наполнителя на транспортную и разделительную полиэтиленовые пленки наносят слой (2-10)\%-ной суспензии углеродных нанотрубок в смеси олигомерных коксообразующей и некоксующейся смол. При выкладке пакета заготовки углепластика в каждый из слоев препрега засыпают углеродные нанотрубки через съемную перфорированную пластину, находящуюся в непосредственном плотном контакте с выкладываемым слоем препрега, повторяющего его размеры. После карбонизации полученную углерод-углеродную заготовку дополнительно уплотняют пропиткой в (2-10)\%-ной суспензии углеродных нанотрубок в растворе поликарбосилана в толуоле.

\section{Способ получения тонких алмазных пленок (RU 2685665 C1)}

Изобретение может быть использовано в различных областях промышленности и науки для получения тонкопленочных упрочняющих покрытий и активных слоев тонкопленочных наноструктур [2]. Предлагается способ получения тонких алмазных пленок на подложке методом вакуумного лазерного воздействия на мишени и конденсацией углерода на подложки, где в качестве мишеней используют предварительно спрессованные таблетки детонационного наноалмаза и таблетки из высокочистого графита, а лазерное воздействие осуществляют в два этапа: вначале сфокусированным излучением лазера на основе алюмоиттриевого граната с длиной волны 1064 нм серией 10-20 импульсов с энергией импульса 3,8-5,8 Дж диспергируют мишень из детонационного наноалмаза и формируют на подложке наноалмазные нуклеационные центры; затем промежутки между нуклеационными центрами заполняют углеродом с преимущественно sp3-связями, сконденсированным из парогазовой фазы, полученной испарением мишени из высокочистого графита путем воздействия расфокусированным лазерным излучением этого же лазера с интенсивностью энергии импульса не ниже $1,6 \cdot 104$ Вт/см². В ходе конденсации углерода на подложку, предварительно заселенную нуклеационными центрами, преимущественно с размерами 5,73 нм, наблюдается их разрастание до частиц размером около 285, 15 нм. Совокупность таких частиц (островков) формирует плоскую тонкопленочную плотноупакованную гексагональную структуру, представляющую собой поликристаллический агрегат из островков, кристаллографически одинаково ориентированных относительно поверхности пленки. 


\section{Роторно-вибрационный смеситель (RU 2685674 C1)}

Изобретение относится к смесительным устройствам для смешивания высокодисперсных и нановеществ и может быть использовано в химической, нефтехимической, пищевой, сельскохозяйственной и других отраслях промышленности [3]. Роторновибрационный смеситель включает корпус, перемешивающий орган и вибратор, содержит крышку корпуса, перемешивающий орган, выполненный в виде пропеллера, установленного соосно над перемешивающим органом якорной формы, причем вибратор выполнен в виде направляющей поворотной гребенки. Изобретение обеспечивает повышение эффективности смешивания высокодисперсных и нановеществ, а следовательно повышение качества готовой смеси за счет применения ультразвуковых колебаний в псевдоожиженном слое.

\section{C1)}

Способ синтеза нанокомпозитов Ag/C (RU 2686223

Изобретение относится к области химии и нанотехнологии. Способ синтеза нанокомпозитов $\mathrm{Ag} / \mathrm{C}$ включает приготовление совместного раствора полиакрилонитрила (ПАН) и нитрата серебра в диметилформамиде (ДМФА), выдержку до полного растворения всех компонентов, удаление диметилформамида путем выпаривания и нагрев полученного твердого остатка [4]. Приготовление совместного раствора полиакрилонитрила и $\mathrm{AgNO}_{3}$ в диметилформамиде осуществляют при температуре $30-70^{\circ} \mathrm{C}$ при следующем соотношении компонентов: полиакрилонитрил 4,7\%, диметилформамид 93,8-94,6\%, $\mathrm{AgNO}_{3} 0,7-1,5 \%$. Выпаривание диметилформамида проводят при $60-80^{\circ} \mathrm{C}$. Осуществляют поэтапный инфракрасный нагрев полученного твердого остатка при давлении 10-2-10-3 мм рт.ст. Сначала проводят предварительный нагрев в течение 5-15 минут при $80-200^{\circ} \mathrm{C}$ со скоростью нагрева не более $50^{\circ} \mathrm{C} /$ мин. Финальный нагрев проводят в течение 5-15 минут при $80-700^{\circ} \mathrm{C}$ со скоростью нагрева не более $50^{\circ} \mathrm{C} /$ мин. Изобретение позволяет упростить получение нанокомпозитов, включающих наночастицы серебра Ag с размером 1928 нм в углеродной матрице, без использования дополнительных внешних восстановительных агентов.

\section{Режущий инструмент с износостойким покрытием (RU 2685820 C1)}

Изобретение относится к металлорежущему инструменту, в частности к режущим пластинам и фрезам, используемым для обработки изделий из труднообрабатываемых материалов, в том числе из титана и его сплавов [5]. Режущий инструмент с износо- стойким покрытием, содержащий режущие кромки, образованные на пересечении передней и задней поверхностей твердосплавной основы режущей части, в котором износостойкое покрытие включает, по меньшей мере, структуру, сформированную из $\mathrm{TiB}_{2}$. Структура, сформированная из $\mathrm{TiB}_{2}$, содержит, по меньшей мере, последовательно нанесенные промежуточный слой из $\mathrm{TiB}_{2}$ и износостойкий слой из $\mathrm{TiB}_{2}$. Промежуточный слой имеет столбчатую металлографическую структуру с преимущественной ориентацией 001. Износостойкий слой имеет в своем составе, по меньшей мере, слой с внутренней структурой с текстурированными наноколоночными зернами с ориентацией $001 \mathrm{c}$ аморфной р-фазой в границах упомянутых зерен. Обеспечивается повышение стойкости режущего инструмента с покрытием, содержащим $\mathrm{TiB}_{2}$.

Способ изготовления изделий с антистатическими свойствами (RU 2685120 C1)

Изобретение относится к области композитных материалов и касается способа изготовления композитного стеклопластикового листа с антистатическими свойствами и получаемого из него изделия [6]. Способ изготовления композитного стеклопластикового антистатического по объему листа толщиной от 0,5 до 10,0 мм для изготовления прессованных изделий заключается в том, что на первой стадии полиэфирную смолу и порошкообразные добавки с нанокомпонентом, который придает листу антистатичность, смешивают в диссольвере с образованием пасты, которую подают в емкости, откуда она на второй стадии наносится на движущиеся под ними пленки, и при этом на второй стадии применяется химическое загущение полиэфирной смолы путем введения в состав пасты загустителя, увеличивающего вязкость для возможности последующего прессования через 3-5 дней, и одновременно с этим армирующее стекловолокно подают в рубочную машину, расположенную над поверхностью пасты, нанесенную на одну из пленок, рубят на отрезки заданной длины и хаотично подают на поверхность слоя пасты, сверху накатывают второй слой из пленки с пастой и подают в уплотнительную систему роликов, где происходит пропитка стекловолокна и удаление пузырьков воздуха, в результате получают лист, который наматывают на стальные ролики, расположенные на стеллаже. Полученный лист нарезают на столе, удаляя кромки, обедненные стекловолокном, при этом обрезки кладут в центр навески в стопку, которую помещают в пресс-форму, и формируют изделие. Изобретение обеспечивает придание листу и готовому из него изделию антистатические свойства по всему объему. 
Способ изготовления алмазного инструмента с наномодифицированной режущей частью (RU 2685917 C1)

Изобретение относится к области изготовления инструмента резания твердых и высокотвердых материалов и может найти применение для изготовления алмазного режущего инструмента, в частности, камнеобрабатывающего алмазного отрезного круга с водным и/или воздушным охлаждением для резки железобетона, кирпича, керамогранита, огнеупорных материалов гранита, мрамора и других минералов [7].

Технический результат достигают тем, что способ изготовления алмазного инструмента с наномодифицированной режущей частью включает приготовление порошковой смеси на основе алмазного порошка и связки, введение в смесь пластификатора, гранулирование, дозирование, холодное прессование режущей части инструмента, горячее прессование, галтовку, соединение режущей части с инструментом и вскрытие алмазов.

Установка плазмохимического синтеза наноразмерных порошков и используемый в ней циклон (RU 2686150 C1)

Установка содержит реактор, корпус которого расположен вертикально и выполнен с возможностью нагрева, ускоритель электронов с энергией электронов 300-1000 кэВ, систему подачи реагента в реактор, содержащую расходную емкость, дозатор, буферную емкость и запорный клапан, вакуумную систему, устройство разделения твердых и газообразных продуктов плазмохимического синтеза, выполненное в виде шнекового циклона с возможностью нагрева его корпуса, и систему отделения растворимых газообразных продуктов плазмохимического синтеза, связанную со шнековым циклоном через электростатический фильтр, при этом выход реактора и вход шнекового циклона разделены автоматическим выпускным клапаном [8].

Изобретение относится к оборудованию плазмохимического синтеза ультрадисперсных порошков, неорганических соединений и композиций, в частности к установке плазмохимического синтеза наноразмерных порошков и шнековому циклону, используемому в ней. Изобретение обеспечивает возможность получения различных видов продукции наноразмерных порошков и композиционных материалов на их основе с высокой химической чистотой на одном и том же оборудовании, а также уменьшение времени технологического перехода от одного процесса к другому и высокий экономический эффект.
Способ синтеза наночастиц металлов осаждением на пористый углеродный материал (RU 2685564 C1)

Изобретение относится к получению наночастиц металла. Способ включает испарение мишени из металла электронным пучком в вакууме и осаждение наночастиц металла [9]. Испарение мишени из металла ведут электронным пучком, направленным под углом 30-90 градусов к поверхности мишени. Обеспечивают пространственное сканирование электронного пучка по двум координатам на мишени с частотами в пределах 5-200 Гц и амплитудой 5 мм в течение 10-1000 ceкунд и временную модуляцию тока пучка с частотой 10-100 Гц со скважностью 1-10. Осаждение наночастиц металла осуществляют из направленного потока на подложку, покрытую пористым углеродным материалом толщиной 0,1-2 мм, насыпной плотностью 0,04-0,06 г/см и установленную на водоохлаждаемом медном экране. Обеспечивается уменьшение поглощения энергии в парах металла, что увеличивает производительность распыления.

Способ изготовления газового сенсора с наноструктурой со сверхразвитой поверхностью и газовый сенсор на его основе (RU 2687869 C1)

Способ изготовления газового сенсора с наноструктурой со сверхразвитой поверхностью заключается в том, что образуют гетероструктуру из различных материалов, в которой формируют газочувствительный слой. После чего её закрепляют в корпусе сенсора, а контактные площадки соединяют с выводами корпуса при помощи контактных проводников, газочувствительный слой формируют в виде наноструктуры со сверхразвитой поверхностью путем двухстадийного химического синтеза, на первой стадии которого формируется однородная тонкой пленка оксида цинка, представляющая собой зародышевый слой, а на второй стадии методом гидротермального синтеза формируются наностержни оксида цинка, образующие сверхразвитую поверхность [10].

Технический результат заключается в обеспечении возможности повышения чувствительности к газам-восстановителям при близкой к комнатной температуре $\left(25-50^{\circ} \mathrm{C}\right)$.

Также представляют интерес для специалистов следующие изобретения в области нанотехнологий:

- Строительный конструкционный элемент [11].

- Способ синтеза композитного углеродного материала с наночастицами металла с переносом части их электронной плотности в углеродную матрицу [12]. 
- Способ изготовления маркёра горючесмазочных материалов [13].

- Система очистки сточных вод с использованием наномодифицированных природных сорбентов [14].

- Нанокристалл, гидрозоль нанокристаллической целлюлозы и способ его получения [15].

- Способ получения мембран для ультрафильтрации водных сред [16].

- Технологии повышения эффективности электропотребления [17].

- Способ получения прозрачной керамики иттрийалюминиевого граната [18].

- Тенденции развития глобальных энергетических рынков[19].

- Способ и устройство атомно-эмиссионного спектрального анализа нанообъектов [20].

- Способ термической очистки углеродных нанотрубок [21].

- Метод получения прочного и токопроводящего волокна путем вытягивания пленок из углеродных нанотрубок [22].

\section{ЗАКЛЮЧЕНИЕ}

Известно, что именно популяризация и внедрение изобретений является важным фактором успеха многих преуспевающих компаний. Например, General Electric, которая вошла в мировую историю как одна из самых инновационных компаний $\mathrm{XX}$ века, является компанией, которая изначально попала в список индекса Доу-Джонса в 1896 году и до сих пор там находится. Поэтому надеемся, что публикуемая в данной рубрике информация будет востребованной и полезной для специалистов. Подтверждением того, что статьи из рубрики «Обзор изобретений» пользуются особой популярностью, является информация о количествах просмотров материалов, наример, в полнотекстовой базе научных журналов открытого доступа Open Academic Journals Index OAJI (США), ссылка - http://oaji.net/journaldetail.html?number $=6931$.

\section{REFERENCES}

1. Beilina N.Yu., Chernenko D.N., Chernenko N.M., Shcherbakova TS, Grudin I.G. Patent 2684538 of the Russian Federation IPC C1. Carbon ceramic fiber-reinforced composite material and method for its production. 2019. Bull. No. 10.

2. Plotnikov V.A., Makarov S.V., Makrushina A.N., Zyryanova A.I., Shutkin A.A. Patent 2685665 of the Russian Federation IPC C1. The method of obtaining thin diamond films. 2019. Bull. No. 12.

3. Belov A.G., Popov V.P., Shakhov V.A., Ushakov Yu.A., Mezhuyeva L.V. and others. Patent 2685674 of the Russian Federation IPC C1. Rotary-vibration mixer. 2019. Bull. No. 12.

4. Kozhitov L.V., Sonkin V.S., Muraleev A.R., Sidin E.G., Maganov D.D., Muratov D.G., Yakushko E.V., Popkova A.V. Patent 2686223 of the Russian Federation IPC C1. The method of synthesis of nanocomposites Ag/C. 2019. Bull. No. 12.

5. Moskvitin A.A., Gubanov A.E., Moskvitin A.A., Maslov A.I., Moskvitin S.A. and others. Patent 2685820 of the Russian Federation IPC C1. Cutting tool with wear-resistant coating. 2019. Bull. No. 12.

6. Ivanov E.V., Kuklin I.S., Showniyev Yu.A., Ramazanov R.M. Patent 2685120 of the Russian Federation IPC C1. A method of manufacturing products with antistatic properties. 2019. Bull. No. 11.

7. Andreev V.A., Gureev A.I., Sevastyanov P.I. Patent 2685917 of the Russian Federation IPC C1. A method of manufacturing a diamond tool with a nanomodified cutting part. 2019. Bull. No. 12.

8. Mikhailov M.N., Sazonov R.V., Kholodnaya G.E. Patent 2686150 of the Russian Federation IPC C1. Installation of the plasma-chemical synthesis of nanosized powders and the cyclone used in it. 2019. Bull. No. 12.

9. Kizner V.G., Streltsov M.V., Novopashin S.A. Patent 2685564 of the Russian Federation IPC C1. Method for the synthesis of metal nanoparticles by deposition on a porous carbon material. 2019. Bull. No. 12.

10. Averin I.A., Bobkov A.A., Karmanov A.A., Moshnikov V.S., Pronin I.A., Yakushova N.D. Patent 2687869 of the Russian Federation IPC C1. A method of manufacturing a gas sensor with a nanostructure with a superdeveloped surface and a gas sensor based on it. 2019. Bull. No. 14.

11. Ivanov LA., Prokopiev P.S. The inventions in nanotechnologies as practical solutions. Part III. Nanotehnologii v stroitel'stve $=$ Nanotechnologies in Construction. 2019, Vol. 11, no.3, pp. 292-303. DOI: 10.15828/2075-8545-2019-11-3-292-303.

12. Berveno V.P., Berveno A.V. Patent of 2689738 of the Russian Federation IPC C1. Method of synthesis of composite carbon material with metal nanoparticles with transfer of a part of their electron density to a carbon matrix. 2019. Bull. No. 16.

13. Tkachev A.G., Memetov N.R., Yagubov V.S., Naghdaev V.K. Patent of 2689420 of the Russian Federation IPC C1. A method of manufacturing a marker of fuel and lubricants. 2019. Bull. No. 16.

14. Malkin P. Wastewater treatment system based on nanomodified natural sorbents. Nanotehnologii v stroitel'stve $=$ Nanotechnologies in Construction. 2018, Vol. 10, no. 5, pp. 56-72. DOI: 10.15828/2075-8545-2018-10-5-56-72. 
15. Udoratina E.V., Torlopov M.A. Patent 2689753 of the Russian Federation IPC C1. Nanocrystal, nanocrystalline cellulose hydrosol and method for producing it. 2019. Bull. No. 16.

16. Anokhina TS, Borisov I.L., Vasilevsky V.P., Volkov A.V., Petrova D.A. and others. Patent 2689595 of the Russian Federation IPC C1. Method for producing membranes for ultrafiltration of aqueous media. 2019. Bull. No. 16.

17. Schetinin E.Yu., Prokopiev P.S. Assessment of energy-saving technologies in the power supply of smart buildings using artificial intelligence. Financial Economics. 2019. №2. p. 666-668. (In Russian).

18. Kosyanov D.Yu., Vornovskikh A.A., Shichalin O.O., Papynov E.K. Patent 2685305 of the Russian Federation IPC C1. The method of obtaining transparent ceramics of yttrium-aluminum garnet. 2019. Bull. No. 11.

19. Nikitin A.A., Dinets D.A., Prokopyev P.S. Financial and economic and geopolitical prospects for the formation of common energy markets of the EAEU. Innovations and investments. 2019. №3. pp. 71-75. (In Russian).

20. Ivanov L.A., Muminova S.R. New technical solutions in nanotechnology. Part 1. Nanotehnologii v stroitel'stve $=$ Nanotechnologies in Construction. 2016, Vol. 8, no. 2, pp. 52-70. DOI: 10.15828/2075-8545-2016-8-2-52-70. (In Russian).

21. Podgaetsky V.M., Gerasimenko A.Yu., Ichchitidze L.P., Polokhin A.A., Selishchev S.V. Patent 2690991 of the Russian Federation IPC C1. The method of thermal purification of carbon nanotubes. 2019. Bull. No. 16.

22. Nasibulin AG, Zhilyaeva MA, Shulga E. Patent 2690821 of the Russian Federation IPC C1. The method of obtaining a strong and conductive fibers by pulling films of carbon nanotubes. 2019. Bull. No. 16.

\section{СПИСОК ЛИТЕРАТУРЫ}

1. Бейлина Н.Ю., Черненко Д.Н., Черненко Н.М., Щербакова Т.С., Грудин И.Г. Углеродкерамический волокнистоармированный композиционный материал и способ его получения // Патент 2684538 РФ МПК С1. 2019. Бюл. № 10.

2. Плотников В.А., Макаров С.В., Макрушина А.Н., Зырянова А.И., Шуткин А.А. Способ получения тонких алмазных пленок // Патент 2685665 РФ МПК С1. 2019. Бюл. № 12.

3. Белов А.Г., Попов В.П., Шахов В.А., Ушаков Ю.А., Межуева Л.В. и др. Роторно-вибрационный смеситель // Патент 2685674 РФ МПК С1. 2019. Бюл. № 12.

4. Кожитов Л.В., Сонькин В.С., Муралеев А.Р., Сидин Е.Г., Маганов Д.Д., Муратов Д. Г., Якушко Е.В., Попкова А.В. Способ синтеза нанокомпозитов Ag/С // Патент 2686223 РФ МПК С1. 2019. Бюл. № 12.

5. Москвитин А.А., Губанов А.Е., Москвитин А.А., Маслов А.И., Москвитин С.А. и др. Режущий инструмент с износостойким покрытием // Патент 2685820 РФ МПК С1. 2019. Бюл. № 12.

6. Иванов Е.В., Куклин И.С., Показаньев Ю.А., Рамазанов Р.М. Способ изготовления изделий с антистатическими свойствами // Патент 2685120 РФ МПК С1. 2019. Бюл. № 11.

7. Андреев В.А., Гуреев А.И., Севастьянов П.И. Способ изготовления алмазного инструмента с наномодифицированной режущей частью // Патент 2685917 РФ МПК С1. 2019. Бюл. № 12.

8. Михайлов М.Н., Сазонов Р.В., Холодная Г.Е. Установка плазмохимического синтеза наноразмерных порошков и используемый в ней циклон // Патент 2686150 РФ МПК С1. 2019. Бюл. № 12.

9. Кизнер В.Г., Стрельцов М.В., Новопашин С.А. Способ синтеза наночастиц металлов осаждением на пористый углеродный материал // Патент 2685564 РФ МПК С1. 2019. Бюл. № 12.

10. Аверин И.А., Бобков А.А., Карманов А.А., Мошников В.С., Пронин И.А., Якушова Н. Д. Способ изготовления газового сенсора с наноструктурой со сверхразвитой поверхностью и газовый сенсор на его основе // Патент 2687869 РФ МПК С1. 2019. Бюл. № 14.

11. Иванов Л.А., Прокопьев П.С. Изобретения в области нанотехнологий, направленные на решение практических задач. Часть III // Нанотехнологии в строительстве. - 2019. - Том 11, № 3. - C. 292-303. - DOI: 10.15828/2075-85452019-11-3-292-303.

12. Бервено В.П., Бервено А.В. Способ синтеза композитного углеродного материала с наночастицами металла с переносом части их электронной плотности в углеродную матрицу // Патент 2689738 РФ МПК С1. 2019. Бюл. № 16.

13. Ткачев А.Г., Меметов Н.Р., Ягубов В.С., Нагдаев В.К. Способ изготовления маркёра горюче-смазочных материалов // Патент 2689420 РФ МПК С1. 2019. Бюл. № 16.

14. Малкин П. Система очистки сточных вод с использованием наномодифицированных природных сорбентов // Нанотехнологии в строительстве. - 2018. - Том 10, № 5. - C. 56-72. - DOI: 10.15828/2075-8545-2018-10-5-56-72.

15. Удоратина Е.В., Торлопов М.А. Нанокристалл, гидрозоль нанокристаллической целлюлозы и способ его получения // Патент 2689753 РФ МПК С1. 2019. Бюл. № 16.

16. Анохина Т.С., Борисов И.Л., Василевский В.П., Волков А.В., Петрова Д.А. и др. Способ получения мембран для ультрафильтрации водных сред // Патент 2689595 РФ МПК С1. 2019. Бюл. № 16.

17. Щетинин Е.Ю., Прокопьев П.С. Исследование энергосберегающих технологий в электроснабжении умных зданий с использованием искусственного интеллекта // Финансовая экономика. - 2019. - № 2. - С. 666-668.

18. Косьянов Д.Ю., Ворновских А.А., Шичалин О.О., Папынов Е.К. Способ получения прозрачной керамики иттрий-алюминиевого граната // Патент 2685305 РФ МПК С1. 2019. Бюл. № 11.

19. Никитин А.А., Динец Д.А., Прокопьев П.С. Финансово-экономические и геополитические перспективы формирования общих рынков энергии ЕАЭС // Инновации и инвестиции. - 2019. - № 3. - С. 71-75. 
REVIEW OF NANOTECHNOLOGICAL INVENTIONS • ОБЗОР ИЗОБРЕTEНИЙ В ОБЛАСТИ НАНОТЕХНОЛОГИЙ

20. Иванов Л.А., Муминова С.Р. Новые технические решения в области нанотехнологий. Часть 1 // Нанотехнологии в строительстве. - 2016. - Том 8, № 2. - С. 52-70. - DOI: 10.15828/2075-8545-2016-8-2-52-70.

21. Подгаецкий В.М., Герасименко А.Ю., Ичкитидзе Л.П., Полохин А.А., Селищев С.В. Способ термической очистки углеродных нанотрубок // Патент 2690991 РФ МПК С1. 2019. Бюл. № 16.

22. Насибулин А.Г., Жиляева М.А., Шульга Е. Метод получения прочного и токопроводящего волокна путем вытягивания пленок из углеродных нанотрубок // Патент 2690821 РФ МПК С1. 2019. Бюл. № 16.

\section{INFORMATION ABOUT THE AUTHORS}

Leonid A. Ivanov, Ph.D. in Engineering, Vice President of the International Academy of Engineering, Member of the International Journalist Federation; Gazetny per., block 9, bld. 4, Moscow, Russian Federation, 125009, L.a.ivanov@mail.ru

Petr S. Prokopiev, Student, Financial University Under the Government of the Russian Federation, International Economic Relations Faculty, e-mail: prokopiev2012@gmail.com

\section{ИНФОРМАЦИЯ ОБ АВТОРАХ}

Иванов Леонид Алексеевич, канд. техн. наук, вице-президент Международной инженерной академии, член Международной федерации журналистов; Газетный пер., д. 9, стр. 4, г. Москва, Россия, 125009, L.a.ivanov@mail.ru

Прокопьев Пётр Сергеевич, студент факультета международных экономических отношений Финансового университета при Правительстве Российской Федерации, e-mail: prokopiev2012@gmail.com 